\title{
Solidification Behavior of Type 308 Stainless Steel Filler Metal
}

\author{
S. A. David \\ G. M. Goodwin
}




\section{DISCLAIMER}

This report was prepared as an account of work sponsored by an agency of the United States Government. Neither the United States Government nor any agency Thereof, nor any of their employees, makes any warranty, express or implied, or assumes any legal liability or responsibility for the accuracy, completeness, or usefulness of any information, apparatus, product, or process disclosed, or represents that its use would not infringe privately owned rights. Reference herein to any specific commercial product, process, or service by trade name, trademark, manufacturer, or otherwise does not necessarily constitute or imply its endorsement, recommendation, or favoring by the United States Government or any agency thereof. The views and opinions of authors expressed herein do not necessarily state or reflect those of the United States Government or any agency thereof. 


\section{DISCLAIMER}

Portions of this document may be illegible in electronic image products. Images are produced from the best available original document. 
Printed in the United States of America. Available from National Technical Information Service

U.S. Department of Commerce

5285 Port Royal Road, Springfield, Virginia 22161

Price: Printed Copy $\$ 4.00$; Microfiche $\$ 3.00$

This report was prepared as an account of work sponsored by an agency of the United States Government. Neither the United States Government nor any agency thereof, nor any of their employees, contractors, subcontractors, or their employees, makes any warranty, express or implied, nor assumes any legal liability or responsibility for any third party's use or the results of such use of any information, apparatus, product or process disclosed in this report, nor represents that its use by such third party would not infringe privately owned rights. 
ORNL / TM-6644

Contract No. W-7405-eng-26

METALS AND CERAMICS DIVISION

SOLIDIFICATION BEHAVIOR OF TYPE 308

STAINLESS STEEL FILLER METAL

S. A. David and G. M. Goodwin

Date Published: January 1979

NOTICE This document contains information of a preliminary nature. It is subject to revision or correction and therefore does not represent a final report.

OAK RIDGE NATIONAL LABOKATORY Oak Ridge, Tennessee 37830 operated by

UNION CARBIDE CORPORATION for the DEPARTMENT OF ENERGY

This Notice

sponsored by was prepared as an account of work United Sutes nor the States Government. Neither the Energy, nor any of the United States Department of contractors, any of their employees, nor any of their any warranty, express or implied, or ascumes any laks liability or responsibility for the accuracy, enmploteno or useiul responsibs for the accuracy, cnmplotonou process disclosed, or represents that its use would not process disclosed, or represen
infringe privately owned right 


\section{THIS PAGE}

\section{WAS INTENTIONALLY LEFT BLANK}




\section{CONTENTS}

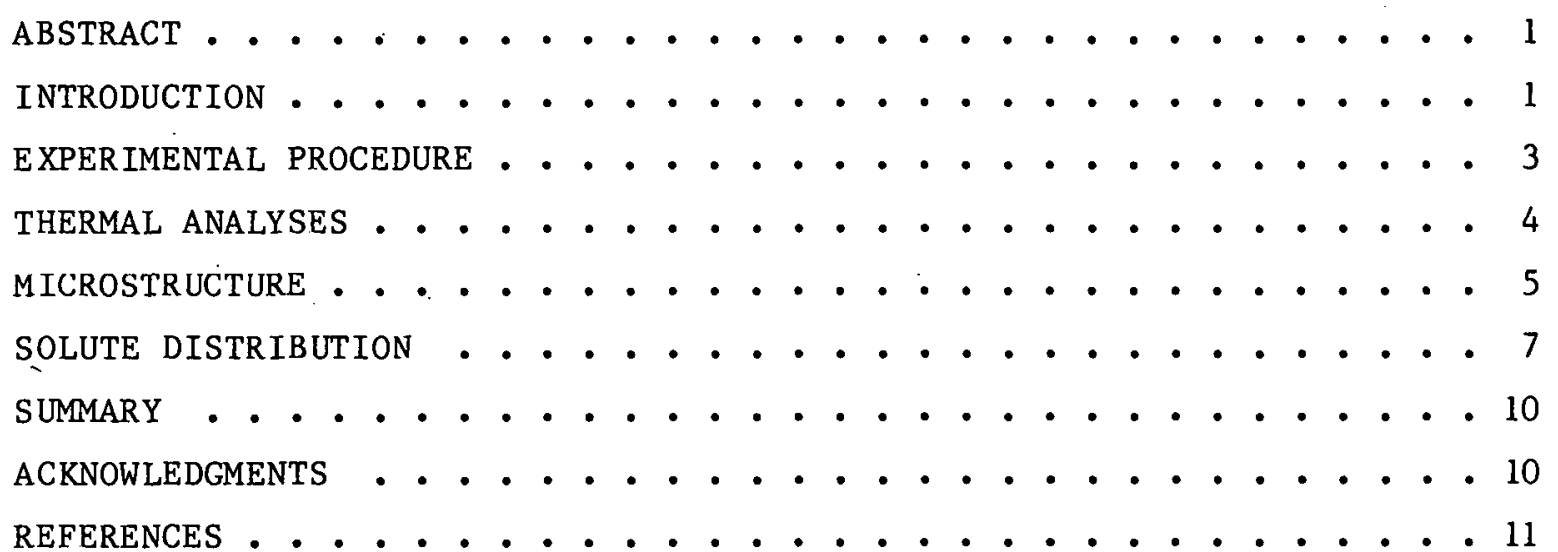




\title{
SOLIDIFICATION BEHAVIOR OF TYPE 308
}

STAINLESS STEEL FILLER METAL

S. A. David and G. M. Goodwin

\begin{abstract}
A series of experiments that combined thermal analysis and interrupted solidification was carried out to understand the solidification behavior of type 308 stainless steel weld metal. Results indicate the following sequence of phase separations for the alloy investigated:

$$
\mathrm{L} \rightarrow \mathrm{L}+\delta \rightarrow \mathrm{L}+\delta+\gamma \rightarrow \gamma+\delta \text {. }
$$

Ferrite observed at room temperature was identified as the untransformed primary $\delta$-ferrite that formed during the initial stages of solidification. The mode of freezing and the extent of solid-state diffusion both control the amount and distribution of ferrite. Microstrutural and microprobe analyses indicated both extensive solid-state transformation and solute redistribution during solidification and cooling from the nonequilibrium solidus to room temperature.
\end{abstract}

\section{INTRODUCTION}

During the past three decades the subject of ferrite ${ }^{*}$ in austenitic stalnless steels has received and continues to receive a great deal of attention. ${ }^{1-3}$ Austenitic stainless steel weld metal normally has a duplex

* The usage of the terms ferrite and $\delta$-ferrite will be synonymous in this article and used interchangeably. 
structure that contains varying amounts of ferrite. We recognize that if sufficient ferrite is present in the weld, the ferrite effectively prevents hot cracking. ${ }^{-6}$ several theories have been advanced to explain this phenomenon. ${ }^{4-10}$ Yet, to date, our understanding of the hot cracking phenomenon is still incomplete. Knowledge of the sequence of phase separation leading to the microstructure and solute distribution observed during and after solidification may significantly improve our understanding of the role of ferrite in preventing hot cracking. The alloy compositions in Fig. 1. show that solidification of austenitic stainless steel weld metal can take place by primary precipitation of

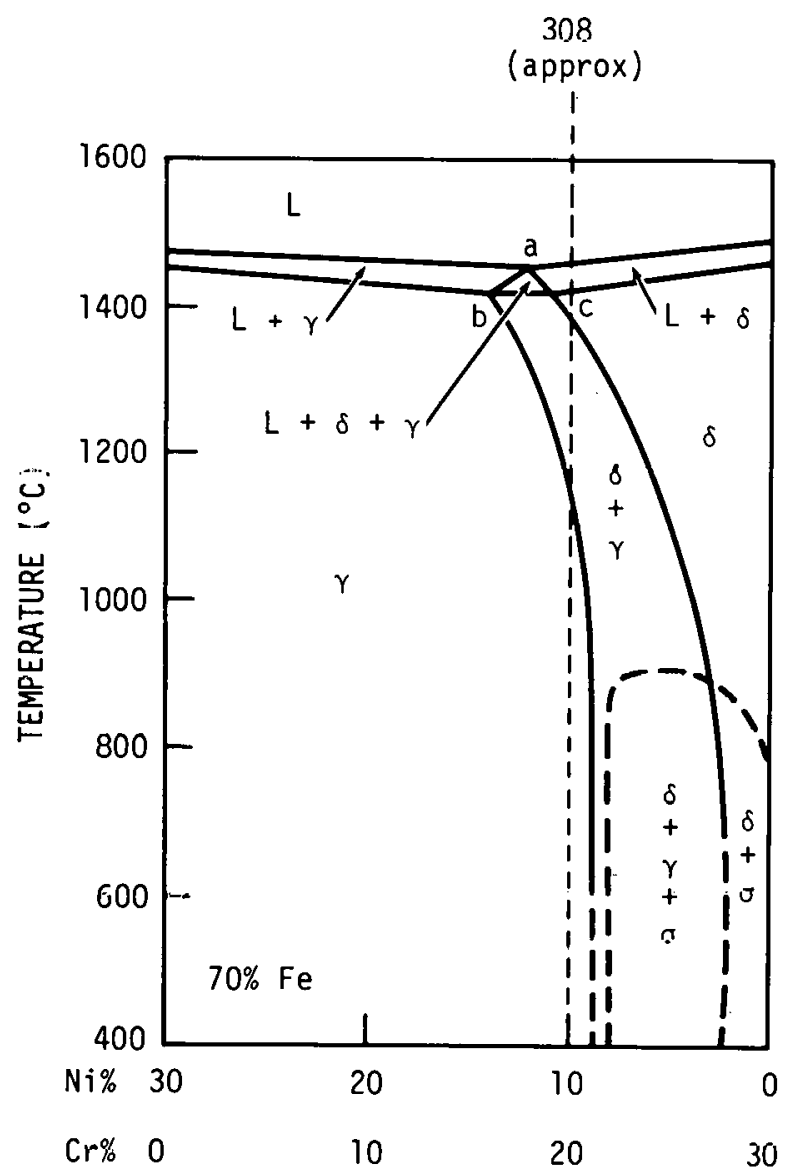

Fig. 1. Vertical Section (at 70 wt \% Fe) of Ternary Equilibrium System Fe-Cr-Ni. Source: I. Masumoto, K. Tamaki, and M. Katsuna, Jap. Weld. Soc. J. 41(11): 1306-14 (1972). 
austenite or ferrite.11 In certain cases, subsequent to the formation of ferrite, austenite envelopment could occur and thus interrupt the formation of ferrite.

The purpose of this investigation was to examine in detail the solidification behavior of type 308 stainless steel filler metal. Thermal analysis and interrupted solidification experiments were designed to correlate the observed microstructural features and solute distribution with solidification behavior.

\section{EXPERIMENTAL PROCEDURE}

Differential Thermal Analysis (DTA) and interrupted solidification experiments were carried out by suspending $25-\mathrm{g}$ samples contained in an alumina crucible in a vertical $\mathrm{Pt}-40 \% \mathrm{Rh}$ resistance heated tube furnace. The samples contained by weight percent: $0.065 \mathrm{C}, 1.52 \mathrm{Mn}, 0.44$ $\mathrm{Si}, 0.02 \mathrm{P}, 0.008 \mathrm{~S}, 20.51 \mathrm{Cr}$, and $10.53 \mathrm{Ni}$, the balance being iron. The furnace tube was sealed at the bottom and top and a constant rate of argon flow was maintained in the furnace. A pure platinum sample was used as the standard during DTA. After the sample was heated to about $50^{\circ} \mathrm{C}$ above the presumed liquidus, it was cooled at a constant rate of about $20^{\circ} \mathrm{C} / \mathrm{min}$. Thermocouples made of $\mathrm{Pt}$ vs $\mathrm{Pt}-10 \% \mathrm{Rh}$ were used to record the temperature differential and the cooling curves on an $x-y$ recorder. Interrupted solidification experiments were carried out by heating the sample to above its liquidus temperature, slowly cooling the sample to a predetermined temperature below the liquidus, and quenching the sample in an ice bath. The progress of the solidification was followed by metallographically analyzing the samples quenched from a series of temperatures within the freezing range of the alloy.

Standard metallographic techniques for austenitic stainless steel were used for microstructural analysis. The samples were etched with a solution containing five parts $\mathrm{HCl}$ and one part $\mathrm{HNO}_{3}$. To determine the segregation characteristics of the alloying elements, microprobe analyses were done on the samples traversing a path crossing a few secondary dendrite arms. Ratios of the intensity at different points to the intensity of the pure element were plotted as a function of distance. 
THERMAL ANALYSES

Results of DTA on the type 308 stainless steel filler metal are shown in Fig. 2. Results of the DTA, the cooling curve of the sample, and the guidance of Fig. 1 permitted us to identify three breaks. These indicated: (1) the primary crystallization of $\delta$-ferrite at approximately $1435^{\circ} \mathrm{C}$; (2) the start of austenite formation at $1370^{\circ} \mathrm{C}$ and envelopment of $\delta$-ferrite; and ( 3 ) a solidus temperature at $1339^{\circ} \mathrm{C}$, respectively. The temperatures of these multiphase reactions were reproduced within $\pm 2{ }^{\circ} \mathrm{C}$ on other samples, as well. The results also indicated that the alloy line position shown in Fig. I does not represent the solidification sequences of type 308 stainless steel filler metal. The presence of other alloying

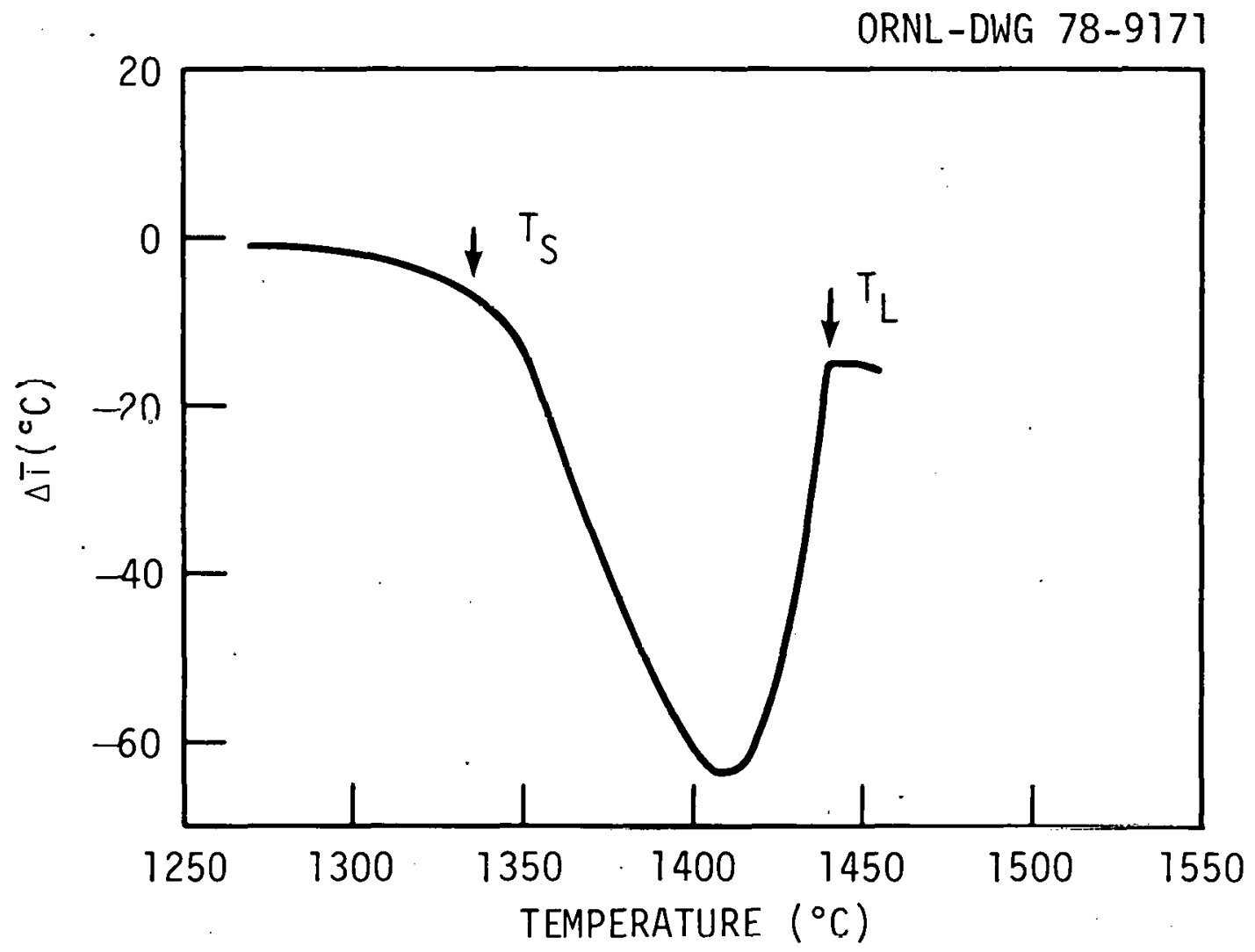

Fig. 2. Results of Differential Thermal Analysis of Type 308 Stainless Steel Filler Metal. Plot of temperature differential between standard platinum and sample vs sample temperature. 
elements in addition to nickel and chromium has changed considerably the alloy line position relative to the phase diagram, such that it partly traverses the triangle of three phase equilibrium.

\section{MICROSTRUCTURE}

Figure 3 shows low-magnification photomicrographs of the samples quenched from various temperatures below the liquidus temperature. Precipitation of primary $\delta$-ferrite occurs on cooling the sample to a temperature just below the liquidus temperature [Fig. $3(\mathrm{a})]$. Here the dark-etching blocky phase is the primary $\delta$-ferrite. The fine structure surrounding the primary phase indicates that the rest of the area was liquid at the moment of quenching. The dark appearance of ferrite is mainly due to the transformation of what was primary $\delta$-ferrite to Widmanstätten austenite. Fredriksson made a similar observation in 18-8 stainless steel ingots. 12 The volume fraction of the primary $\delta$-ferrite continues to increase as the temperature decreases below the liquidus. However, at $1370^{\circ} \mathrm{C}$, as shown in Fig. 3(b), an envelopment of austenite around the primary $\delta$-ferrite occurs. A high-magnification photomicrograph of the transformed ferrite enveloped by austenite is shown in Fig. 4. Magnetic etching identified the dark phase in the photomicrograph as $\delta$-ferrite. In a way the transformation of $\delta$-ferrite to Widmanstätten austenite clearly marks the boundary between primary ferrite and austenite at the time of quenching. From the point of complete envelopment further transformation $-\mathrm{L} \rightarrow \gamma$ and $\delta \rightarrow \gamma-$ proceeds at the $\gamma-\mathrm{L}$ and $\gamma-\delta$ interfaces. As the sample cools to a temperature slightly below that of the solidus $\left(1339^{\circ} \mathrm{C}\right)$, the transformation at the $\gamma-\mathrm{L}$ interface goes to completion, leaving behind a skeletal network of untransformed delta ferrite along the core of the primary and secondary dendrite arms [Fig. $3(c)$ ]. This residual ferrite appears to be very stable on quenching. Interdendritic ferrite due to solute segregation was absent in the samples examined. Additionally, the amount of residual $\delta$-ferrite decreased further on slowly cooling the sample from solidus to room temperature. 

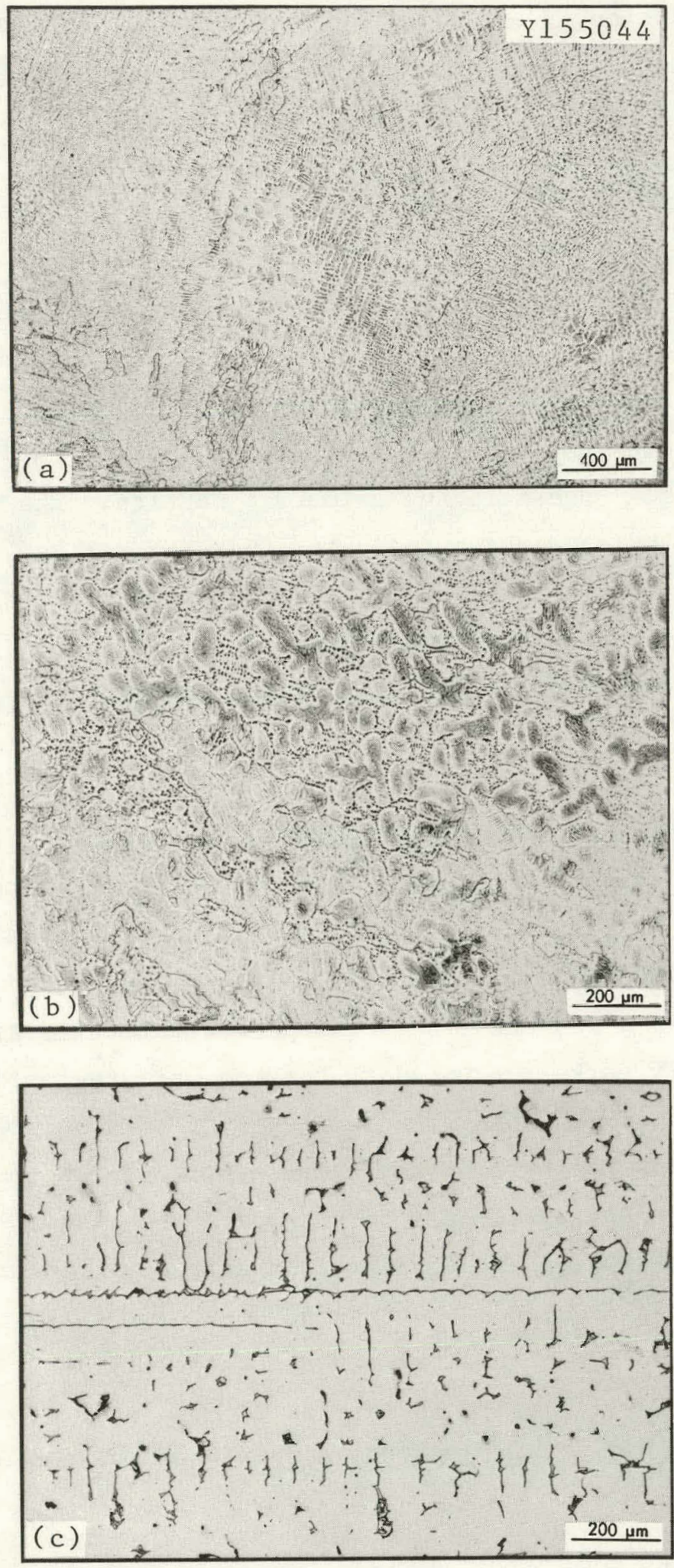

Fig. 3. Photomicrographs of Interrupted Solidification on Samples Quenched from (a) $1430^{\circ} \mathrm{C}$, (b) $1365^{\circ} \mathrm{C}$, and (c) $1335^{\circ} \mathrm{C}$. 


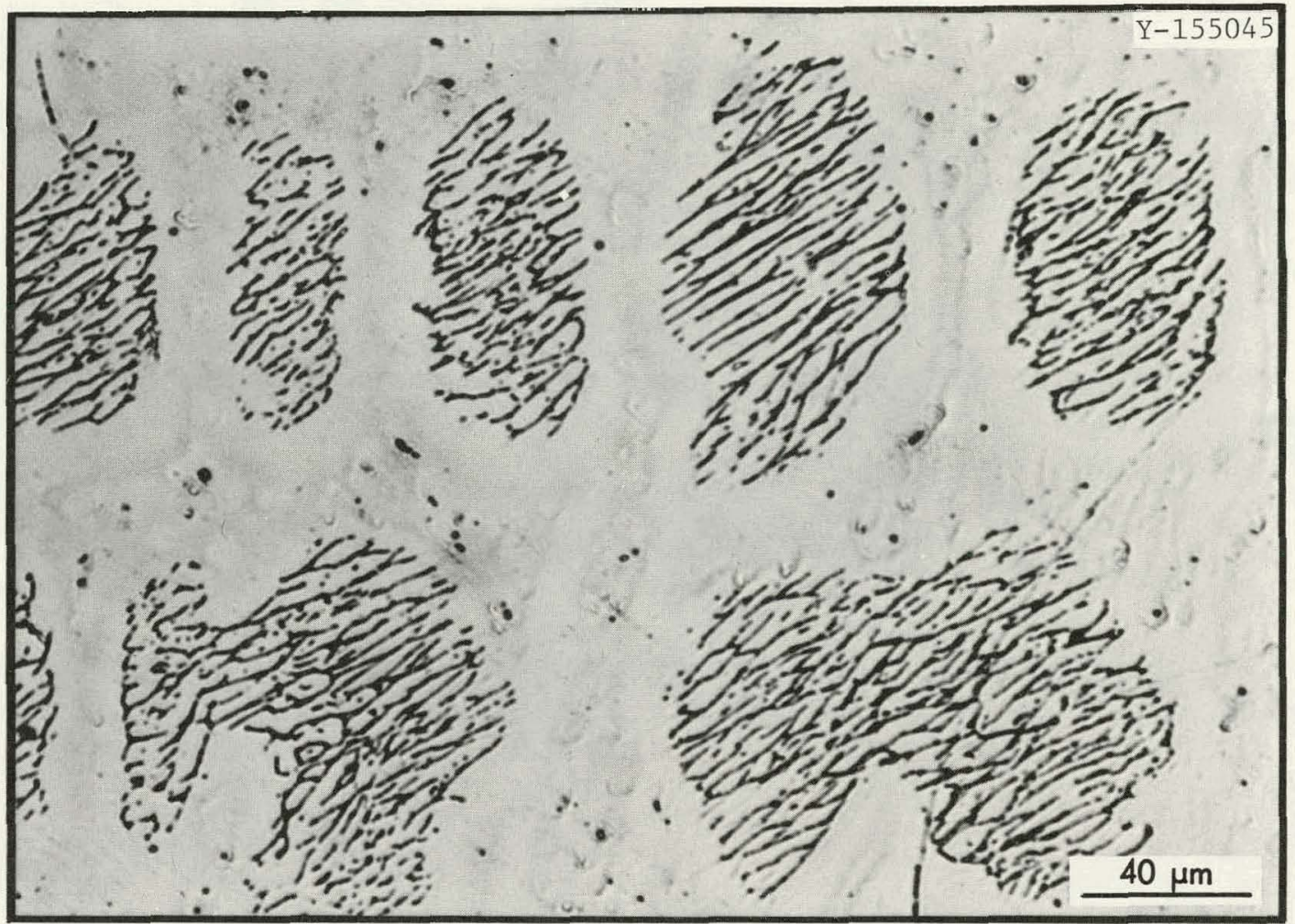

Fig. 4. High-Magnification Photomicrograph of Interrupted Solidification Sample Quenched from $1365^{\circ} \mathrm{C}$.

\section{SOLUTE DISTRIBUTION}

Figure 5 shows the distribution of chromium, nickel, silicon, and manganese across secondary dendrite arms in the same area of the sample shown in Fig. 3(a). From the intensity ratios with the sample as an internal standard, the primary $\delta$-ferrite regions have been found to contain 2 wt \% more chromium and 2 wt \% less nickel than the austenite. The distribution of manganese and silicon was fairly uniform. Figure 6 shows the distribution of chromium, nickel, silicon, and manganese across a ferrite arm in the same area of the sample as shown in Fig. 3(c). The ferrite regions contained approximately 5 wt \% more chromium and 4 wt \% less nickel than the austenite. Apparently, the level of chromium increased significantly in the ferrite, while that of nickel decreased during the $\delta \rightarrow \gamma$ transformation. The high level of chromium in the residual ferrite may have been due to the transport of partitioned chromium into 

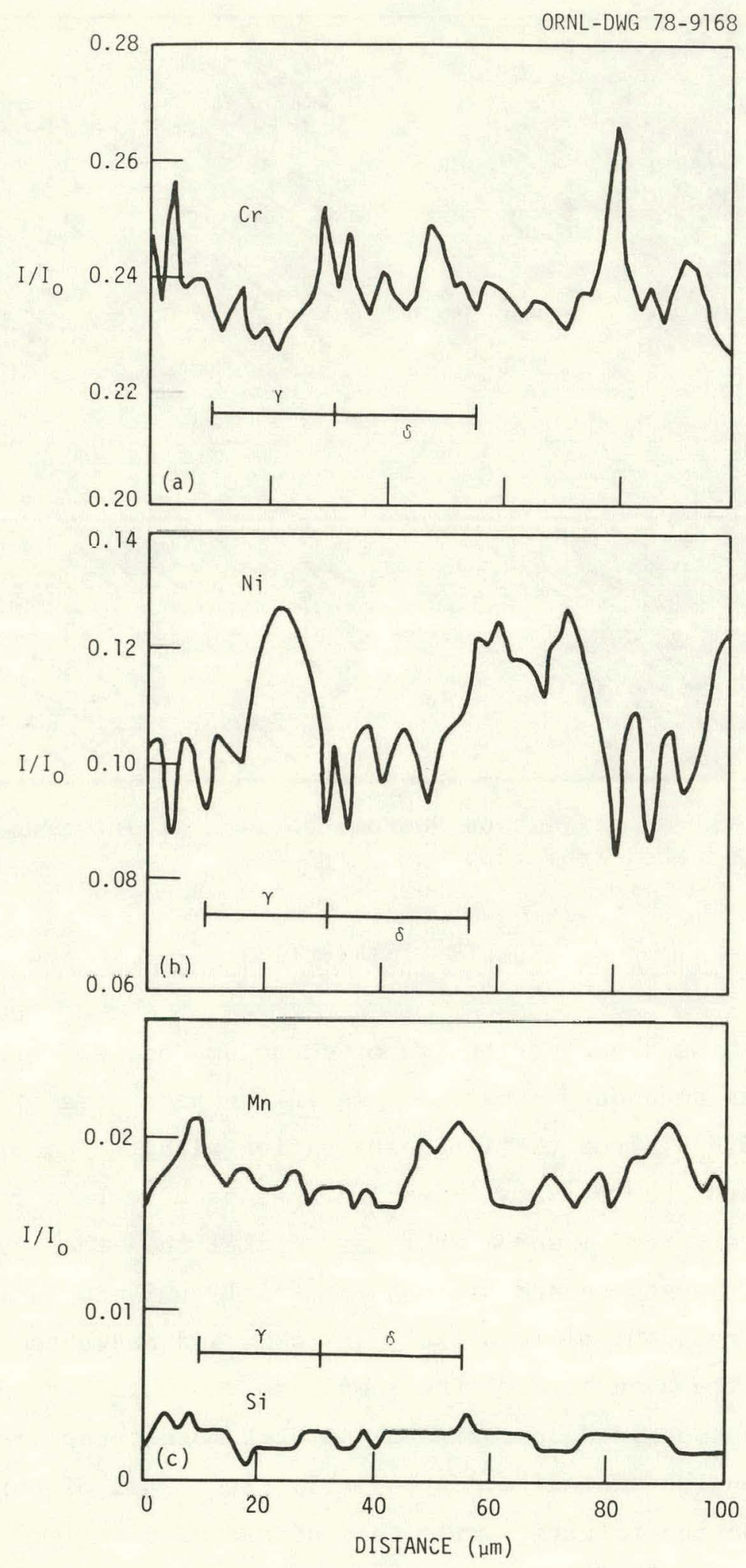

Fig. 5. The Distribution of (a) Chromium, (b) Nickel, and (c) Silicon and Manganese Across Secondary Dendrite Arms in the Same Area of the Sample as shown in Fig. 3(a). 

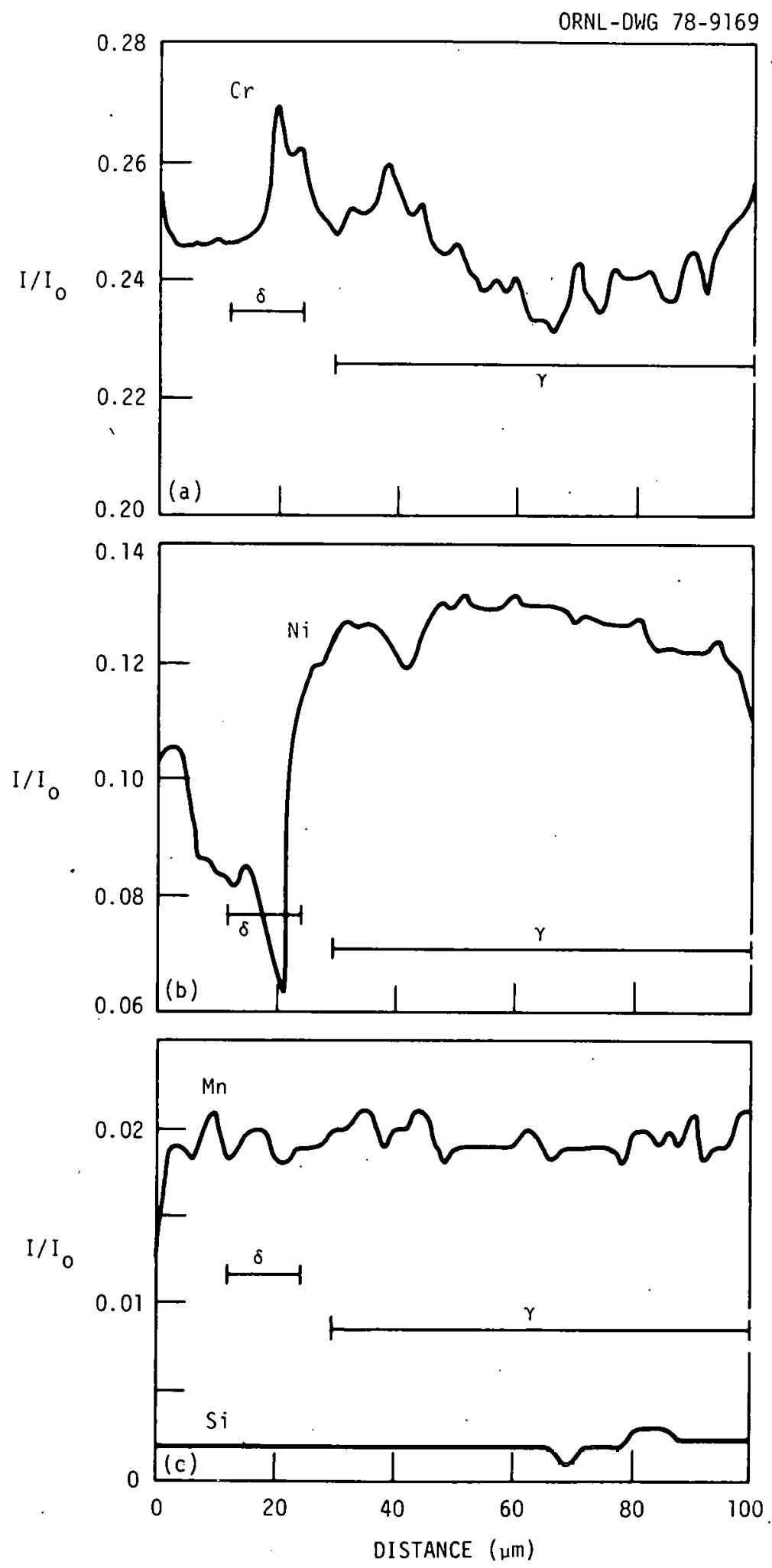

Fig. 6. The Distribution of (a) Chromium, (b) Nickel, and (c) Silicon and Manganese Across Secondary Dendrite Arms in the Same Area of the Sample as Sliown in Fig. 3(c). 
$\delta$-ferrite, with further redistribution of chromium occuring within the ferrite by volume diffusion during $\delta \rightarrow \gamma$ solid-state transformation. 13 This high level of chromium seemed to stabilize the ferrite and thus prevented it from transforming to Widmanstätten austenite during the quench, as discussed earlier.

\section{SUMMARY}

In the light of these results we may conjecture that the type 308 stainless steel filler metal studied generally solidifies by $\mathrm{L} \rightarrow \mathrm{L}+\delta \rightarrow \mathrm{L}$ $+\delta+\gamma \rightarrow \gamma+\dot{\delta}$ transformations. Delta-ferrite in the duplex structure observed at room temperature has been identified as the residual ferrite due to incomplete $\delta-\gamma$ solid-state transformation. Extensive solute redistribution occurs during the transformation of primary $\delta$-ferrite to austenite, leading to enrichment of ferrite by chromium. This increases the stability of the residual $\delta$-ferrite.

\section{ACKNOWLEDGMENTS}

The authors wish to acknowledge C. T. Liu and R. A. Vandermeer for their helpful technical and editorial suggestions and to J. D. Hudson for his assistance with the experimental setup during this investigation. We also acknowledge R. J. Gray, R. S. Crouse, and C. P. Haltom for their assistance in magnetic etching, microprobe analysis, and metallography, respectively. Nan Richards edited and Dianne Spear prepared the manuscript.

\section{REFERENCES}

1. A. L. Schaeffler, Met. Prog. 56: 680-680B (1949).

2. W. T. DeLong and E.O.G. Szumachowski, WeZd. J. (New York) 35: 521-s528-s (November 1956).

3. W. T. Delong, WeZd. J. (Miami) 53: 273-s-286-s (July 1974).

4. J. C. Borland and R. N. Younger, Brit. WeZd. J. 7: 22-60 (January 1960).

5. F. C. Hull, Weld. d. (New York) 46: 399-s-409-s (September 1967). 
6. Y. Arata, F. Matsuda, and S. Katayama, Jap. WeZd. Res. Inst. Trans. $5(2): 35$ (1976).

7. P. P. Puzak, W. R. Apblett, and W. S. Pellini, Weld. J. (Miami) 35: 9-s-17-s (December 1976).

8. W. S. Pellini, Foundry 80: 125 (1952).

9. W. R. Apblett and W. S. Pellini, Weld. J. (Neiw York) 33: 83-s-90-s (December 1954).

10. J. C. Borland, Brit. Weld. J. 7: 508-12 (August 1960).

11. I. Masumoto, K. Tamaki, and M. Katsuna, Jap. WeZd. Soc. J. 41(11): 1306-14 (1972).

12. H. Fredriksson, MetalZ. Trans. 3: 2989-97 (November 1972).

13. C. E. Lyman, P. E. Mauning, D. J. Daugette, and E. Hal1, Scanning EZectron Microse. 1: 213 (1978). 
THIS PAGE

\title{
WAS INTENTIONALLY
}

\author{
LEFT BLANK
}


ORNL/TM-6644

INTERNAL DISTRIBUTION

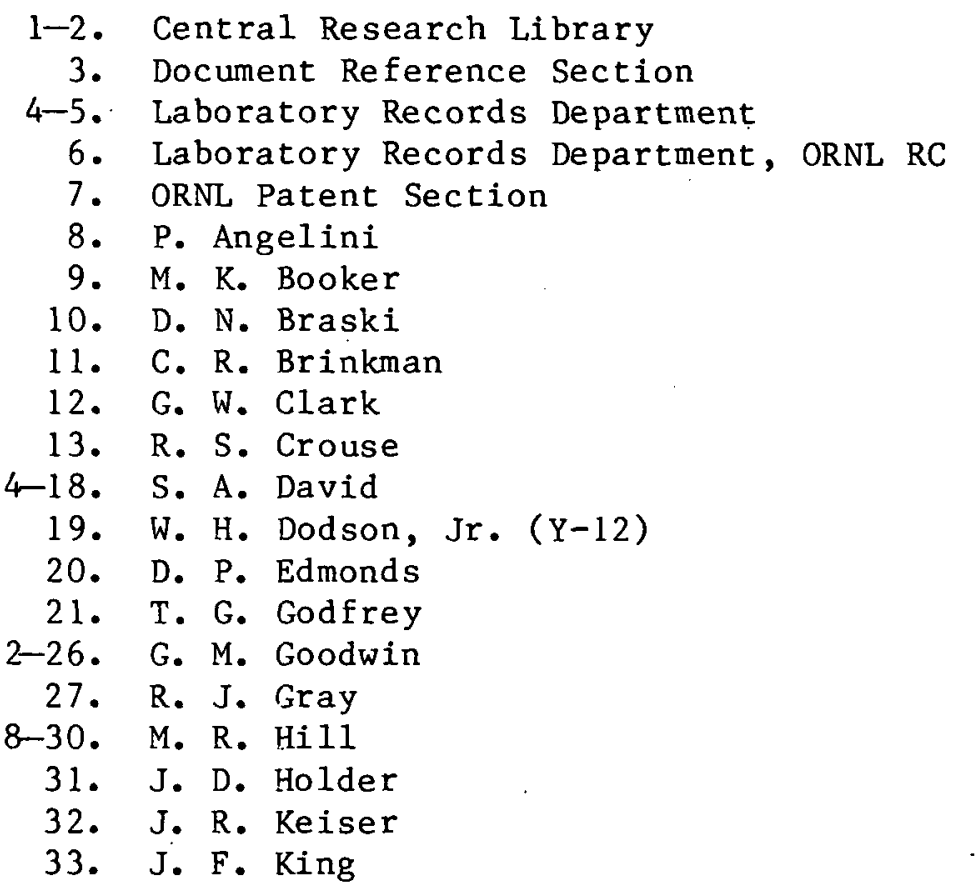

34. R. T. King

35. C. T. Liu

36. C. J. Long

37. P. J. Maziasz

38. J. W. McEnerney

39. A. J. Moorhead

40. H. E. Reesor

41. T. C. Reiley

42. T. K. Roche

43. J. E. Selle

44. G. M. Slaughter

45. J. H. Smith

46. J. O. Stiegler

47. R. W. Swindeman

48. P. F. Tortorelli

49. R. O. Williams

50. R. W. Balluffi (Consultant)

51. W. R. Hibbard, Jr. (Consultant)

52. M. J. Mayfield (Consultant)

53. J. T. Stringer (Consultant)

EXTERNAL DISTRIBUTION

54-57. USDOE, Division of Materials Sciences, Washington, DC 20545
J. S. Kane
L. C. Ianniello
D. K. Stevens
S. Wolf

58. USDOE, Oak Ridge Operations Office, P.O. Box E, Oak Ridge, TN 37830 Assistant Manager, Energy Research and Development

59-85. USDOE, Technical Information Center, Office of Information Services,, P.0. Box 62, Oak Ridge, TN 37830 